\title{
Friction between Self-Lubricating Rings and Travellers and Their Wear
}

By Keiji Kanai, Hiroyuki Kanai and Yasuhiro Kanbara, Merbers, TMSJ

Kanai Juyo Kogyo Co., Ltd., Amagasaki, Hyogo Pref.

\begin{abstract}
The purpose of this research is to discover experimentally the characteristics of the friction between self-lubricating rings and travellers and their consequent wear.

With the aid of a Ring Traveller Friction Tester, the authors have investigated the degree of friction between rings and travellers and the amount of their wear. Lubricating oil of various viscosity degrees was used in the investigation. Findings :

(1) The viscosity degree of lubricating oil has no bearing on the wear of rings, although their wear varies with the type of the ring.

(2) The viscosity degree of lubricating oil and the type of the oiling mechanism used do have a bearing on the wear of travellers.

(3) The viscosity degree of lubricating oil has no bearing on the coefficient of ring-traveller friction, although the coefficient of friction varies with the type of the ring.
\end{abstract}

\section{Introduction}

Large packages and speed-up are major current efforts of the spinning industry to improve the efficiency of spinning and twisting frames.

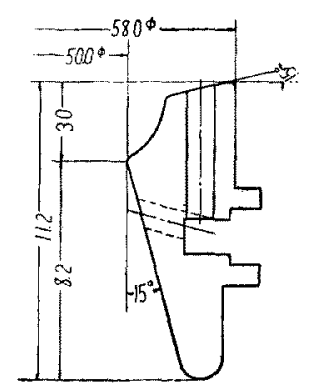

Conical type OL ring (A)

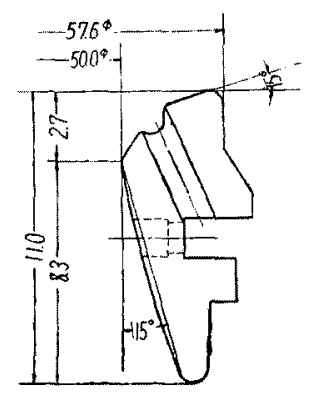

Conical type OL ring (B)

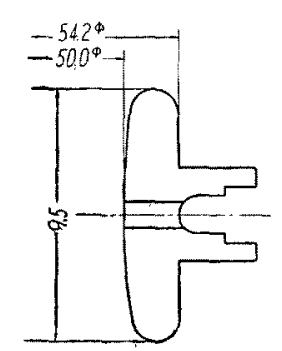

Vertical type OL ring (A)

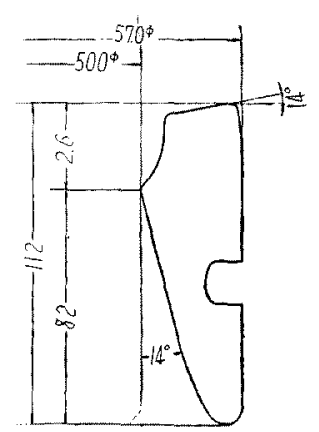

Conical type OM ring (C)
Large packages and speed-up demand a reduction in the ring-traveller friction.

Self-lubricating rings are specifically designed to meet this demand. Self-lubricating rings now in use may be divided roughly into two types. One type is made of case-hardening steel or bearing steel and has lubricating bores or grooves. We call this type an OL ring. The other type is made of sintered ferro-alloy and is saturated with oil. We will call this type an OM ring.

The authors have studied the coefficient of friction of the ring and traveller and their wear with the use of a Ring Traveller Friction Tester and lubricating oil of varying viscosity degrees. The authors' purpose is to obtain fundamental data which can be used as a guide in the design-

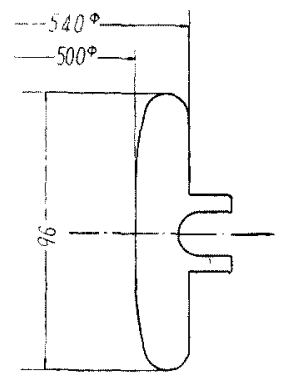

Vertical type OM ring (C)

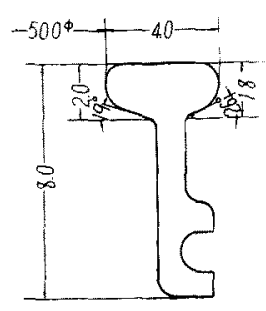

Horizontal type OM ring (C)
Fig. 1. Forms of ring flanges of self-lubricating rings. 
ing of a new oiling mechanism and in deciding what type of self-lubricating ring to use and what metal it should be made of.

\section{Rings and Travellers Tested}

\section{1-1. Types of the Rings and Their Oiling Mechanisms}

$\mathrm{OL}$ and $\mathrm{OM}$ rings were tested (Table 1). They are used to spin wool, synthetic fibers and their blends. The forms of their flanges are shown in Figure 1.

\section{1-2. Metals of Which Made}

The metals of which OL and OM rings are made are given in Table 2. Figure 2 is a microscopic photo showing the structure of an OM

Table 1. Rings Tested

\begin{tabular}{|c|c|c|c|c|}
\hline \multirow[t]{2}{*}{ Types } & \multicolumn{2}{|c|}{$\begin{array}{c}\text { Forms of } \\
\text { flanges }\end{array} \quad \begin{array}{c}\text { Dia. } \\
(\mathrm{mm})\end{array}$} & \multicolumn{2}{|c|}{ Oiling mechanism $\begin{array}{c}\text { Number } \\
\text { of rings } \\
\text { tested }\end{array}$} \\
\hline & $\begin{array}{l}\text { Conical type } \\
\text { (A) }\end{array}$ & 50 & $\begin{array}{l}\text { Holder oil-pot } \rightarrow \\
\text { bores ( } 1 \text { at top, } 3 \text { inside:) }\end{array}$ & 4 \\
\hline \multirow[t]{3}{*}{ OL rings } & $\begin{array}{l}\text { Vertical type } \\
\text { (A) }\end{array}$ & 50 & $\begin{array}{l}\text { Holder oil-pot } \rightarrow \\
\text { bores ( } 3 \text { inside) }\end{array}$ & 4 \\
\hline & $\begin{array}{c}\text { Conical type } \\
\text { (B) }\end{array}$ & 50 & $\begin{array}{l}\text { Holder oil pot } \rightarrow \\
\text { groov ( } 1 \text { at top, } 3 \text { inside) }\end{array}$ & 4 \\
\hline & Conical type & 50 & $\begin{array}{l}\text { Holder oil-pot } \rightarrow \\
\text { oil held in it }\end{array}$ & 1 \\
\hline \multirow[t]{2}{*}{ OM rings } & $\begin{array}{l}\text { Vertical type } \\
\text { (C) }\end{array}$ & 50 & $\begin{array}{l}\text { Holder oil-pot } \rightarrow \\
\text { oil held in it }\end{array}$ & 1 \\
\hline & $\begin{array}{l}\text { Horizontal } \\
\text { type (C) }\end{array}$ & 50 & $\begin{array}{l}\text { Holder oil-pot } \rightarrow \\
\text { oil held in it }\end{array}$ & 4 \\
\hline
\end{tabular}

(A). (B) and (C) were from different makers.

Table 2. Metals of Which Tested Rings Were Made

\begin{tabular}{llr}
\multicolumn{1}{c}{ Types } & Quenching structure & \multicolumn{2}{c}{$\begin{array}{c}\text { Carbon content } \\
\text { of surface }(\%)\end{array}$} \\
OL rings & & \\
Conical type (A) $\begin{array}{l}\text { Surface: fine martensite } \\
\text { Center : ferrite }\end{array}$ & 1.1 \\
Vertical type (A) $\begin{array}{l}\text { Surface: fine martensite } \\
\text { Center ferrite }\end{array}$ & 1.1 \\
Conical type (A) Whole : fine martensite & 1.0 \\
\hline $\begin{array}{l}\text { OM rings } \\
\text { Conical type (C) Mostly: fine martensite }\end{array}$ & 1.0 \\
$\begin{array}{c}\text { Vertical type (C) Entirely: coase accicular } \\
\text { and trootite }\end{array}$ & 1.0 \\
$\begin{array}{c}\text { Horizontal } \\
\text { type (C) Entirely: fine martensite }\end{array}$ & 1.0 \\
\hline
\end{tabular}

ring. The porosity of the OM ring and the weight of the oil with which it is saturated are shown in Table 3.

\section{1-3. Hardness}

The hardness of the $\mathrm{OL}$ and $\mathrm{OM}$ rings is shown in Table 4.

\section{1-4. Travellers}

Travelle rs of all types tested were as nearly the same in weight as possible. Five travellers
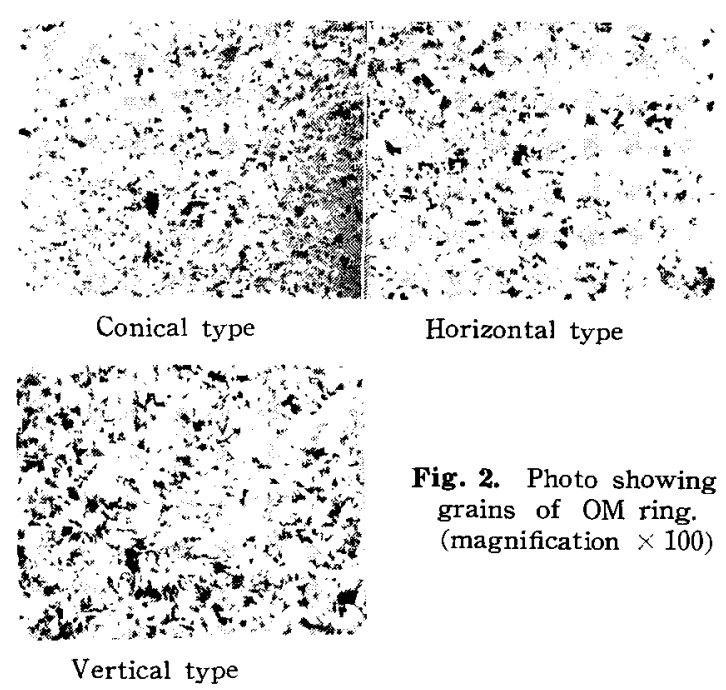

Table 3. Porosity of Rings and Amount of Oil Saturated with

$\begin{array}{cccc}\text { Types } & \begin{array}{c}\text { Conical type } \\ \text { (C) }\end{array} & \begin{array}{c}\text { Vertical type } \\ \text { (C) }\end{array} & \begin{array}{c}\text { Horizontal } \\ \text { type } \\ \text { (C) }\end{array} \\ \begin{array}{l}\text { Porosity (\%) } \\ \text { Amount of oil }\end{array} & 20.7 & 22.3 & 23.2 \\ \begin{array}{l}\text { Amaturated with } \\ \text { satura }\end{array} & 1.0 \mathrm{~g} & 0.7 \mathrm{~g} & 0.6 \mathrm{~g} \\ \end{array}$

Table 4. Hardness of Rings Unit: Shore hardness

\begin{tabular}{|c|c|c|c|c|c|c|}
\hline \multirow[b]{2}{*}{ Hardness } & \multicolumn{3}{|c|}{$\mathrm{OL}$ rings } & \multicolumn{3}{|c|}{ OM rings } \\
\hline & $\begin{array}{l}\text { Conic- } \\
\text { al type } \\
\text { (A) }\end{array}$ & $\begin{array}{l}\text { Vertic- } \\
\text { al type } \\
(\AA)\end{array}$ & $\begin{array}{l}\text { Conic- } \\
\text { al type } \\
\text { (B) }\end{array}$ & $\begin{array}{l}\text { Conic- } \\
\text { al type } \\
\text { (C) }\end{array}$ & $\begin{array}{l}\text { Vertic- } \\
\text { e al type } \\
\text { (C) }\end{array}$ & $\begin{array}{l}\text { Hori- } \\
\text { zontal } \\
\text { type } / C\end{array}$ \\
\hline Surface & 91.0 & 90.5 & 86.0 & 28.5 & 28.0 & 38.0 \\
\hline $\begin{array}{l}\text { Cross } \\
\quad \text { section }\end{array}$ & 27.1 & 63.5 & 59.8 & 26.0 & 29.5 & 33.0 \\
\hline
\end{tabular}

Note: OL rings measured by Vickers micro hardness tester (load: $500 \mathrm{~g}$ ). OM rings measured by Rockwell hardness tester (A scale). Hardness degrees listed are the mean values, converted into Shore hardness, of measurement of three points of surface and cross section of each ring by Rockwell or Vickers hardness testers. 
of each type were tested in combination with one ring (Table 5).

Travellers of hardnesses within the limits of Vickers hardness $660-690$ were tested so as to reduce the hardness difference between them to a minimum. The travellers were made of a metal which met the specifications of JIS (Japan Industrial Standards) SWRH 6A.

\section{1-5. Lubricating Oil}

The lubricating oil used in our test was a compounded oil for self-lubricating rings a mineral oil mixed with chloride as an extreme pressure agent. The characteristics of the oil are shown in Table 6.

\section{Method of Experiment}

\section{2-1. Ring-Traveller Friction Tester}

We used a 10-spindle type Ring Traveller Friction Tester in this experiment. The mechanism of the tester and the method used to measure friction torque are as explained in a previous article[1] by the authors.

Table 5. Combinations of Travellers and Rings

\begin{tabular}{lcccc}
\hline Types of rings & $\begin{array}{c}\text { Traveller } \\
\text { type }\end{array}$ & $\begin{array}{c}\text { Count of } \\
\text { traveller }\end{array}$ & $\begin{array}{c}\text { Weight of } \\
\text { traveller }\end{array}$ & $\begin{array}{c}\text { Number of } \\
\text { travellers } \\
\text { tested }\end{array}$ \\
\hline Conical type & SBA & No. 26 & $0.075 \mathrm{~g}$ & $5 / \mathrm{ring}$ \\
Vertical type & SK & No. 26 & $0.075 \mathrm{~g}$ & $5 / \mathrm{ring}$ \\
Horizontal type & G & No. 3 & $0.075 \mathrm{~g}$ & $5 / \mathrm{ring}$
\end{tabular}

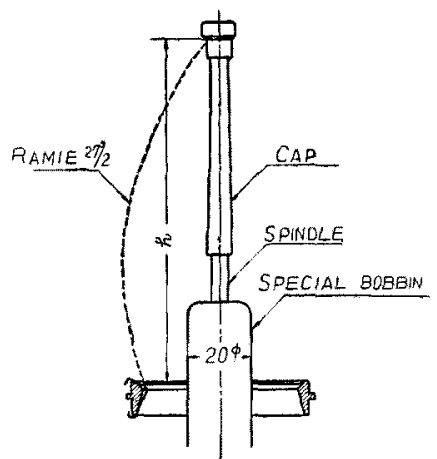

\begin{tabular}{lcc}
\multicolumn{1}{c}{ Ring } & $\begin{array}{c}\text { Centrifugal } \\
\text { force }\end{array}$ & $\mathrm{h}$ \\
\hline Conical type & $85.6 \mathrm{~g}$ & $118 \mathrm{~mm}$ \\
Vertical type & $85.6 \mathrm{~g}$ & $118 \mathrm{~mm}$ \\
Horizontal type & $89.0 \mathrm{~g}$ & $115 \mathrm{~mm}$ \\
\hline
\end{tabular}

Fig. 3. Outline of conditions of experiment.

\section{2-2. Conditions of Experiment}

Spindle speed: $\quad$ 7,000 r.p.m.

Temperature and relative humidity: $20 \sim 25^{\circ} \mathrm{C}, 60 \sim 70 \%$ R.H.

Under the conditions outlined in Figure 3 we tested two factors at the same time - the kinds of the rings and the viscosity of the lubricating oil - repeating the test four times in a random layout. The results were analysized by a two-way layout analysis of variance.

\section{2-3. Cleaning and Oiling of Rings}

The rings we cleaned every four hours. Each time the cleaning consisted of leaving them three hours in trichlorethylene $60^{\circ} \sim 80^{\circ} \mathrm{C}$ hot and then degreasing them completely by compressive air.

The OL rings were oiled by oiling the lubricator (cotton yarn). The OM rings were oiled, through compressor oiling implements, with an oil heated at $60^{\circ} \sim 80^{\circ} \ldots$ after a measurement of the wear of the rings. The amount of the oiling of the OM rings was about $60 \%$ of the capacity of the oil pot attached to the holder on each ring.

Table 6. Characteristics of Lubricant

\begin{tabular}{cccc} 
Lubricants & $\begin{array}{c}\text { Viscosity at } \\
20^{\circ} \mathrm{C} \\
\text { (centipose) }\end{array}$ & $\begin{array}{c}\text { Oiliness } \\
\text { (film } \\
\text { strength })\end{array}$ & Stability \\
\hline CL ring oil No. 15 & $180-200$ & $20 \mathrm{~kg} / 0.1 \mathrm{~mm}^{2}$ & $\begin{array}{c}150^{\circ} \mathrm{C} / 10 \\
\text { hours }\end{array}$ \\
CL ring oil No. 30 & $3,240-3,260$ & $20 \mathrm{~kg} / 0.1 \mathrm{~mm}^{2}$ & $\begin{array}{c}150^{\circ} \mathrm{C} / 10 \\
\text { hours }\end{array}$ \\
\hline
\end{tabular}

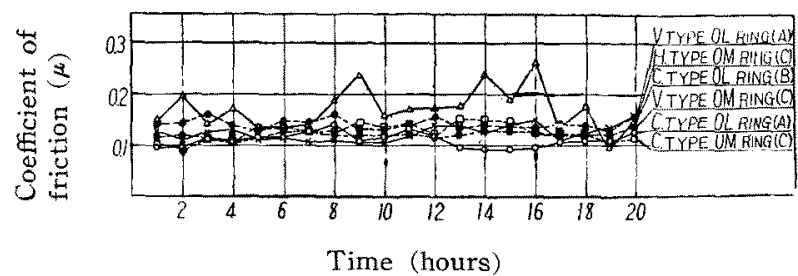

(a) Coefficient of friction if lubricant $\mathrm{CL}$ No. 15 used

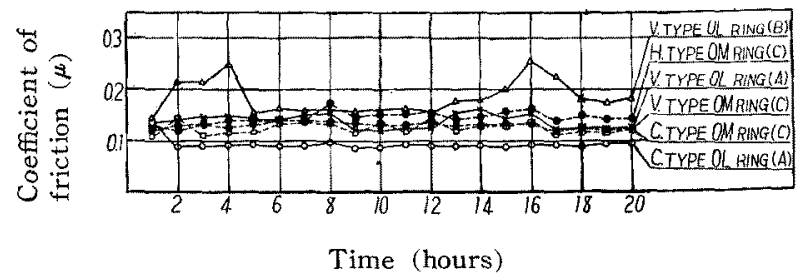

(b) Coefficient of friction if lubricant CL No. 30 used

Fig. 4. Relation between coefficient of ring and traveller and duration of test 


\section{Results}

\section{3-1. Wear and Coefficient of Friction}

Figure 4 shows the relation between the mean value of the coefficient of the ring-traveller friction and the duration of the test; Figure 5, between the mean value of the wear of the rings and the duration of the test; and Figure 6 , between the mean value of the wear of the travellers and the duration of the test.

The mean value of the wear of the rings after 20-hour tests, the mean value of the wear of the travellers after four-hour tests and the mean value of the coefficient of the ring-traveller friction after 20-hour tests were obtained.

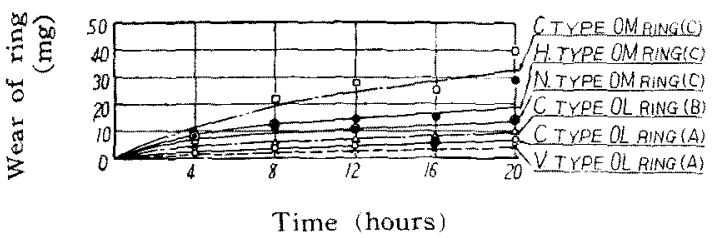

(a) Wear of ring if lubricant $\mathrm{CL}$ No. 15 used

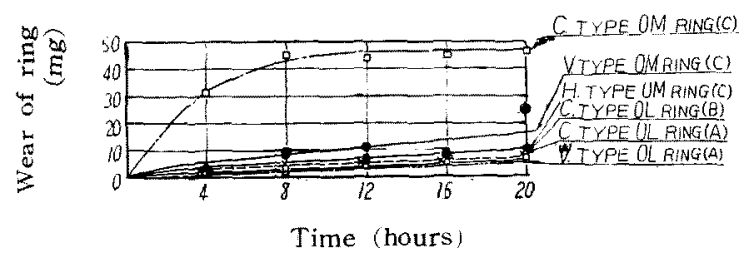

(b) Wear of ring if lubricant $\mathrm{CL}$ No. 30 used

Fig. 5. Relation between coefficient of friction of ring and traveller and duration of test.

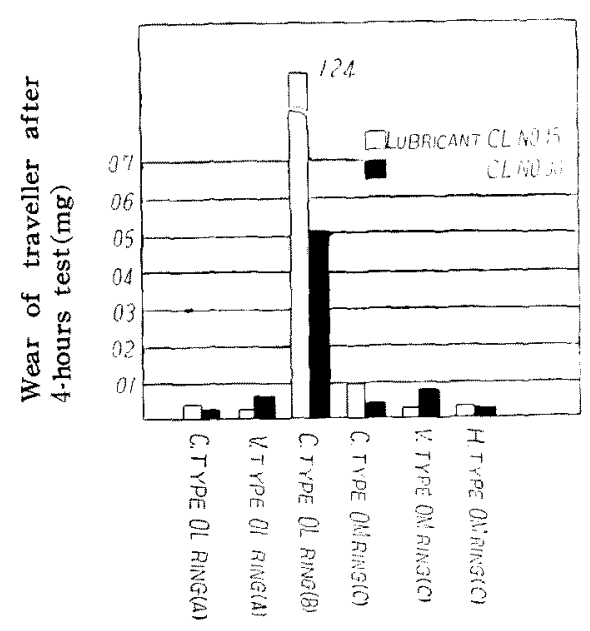

Fig. 6. Viscosity degree of lubricant vs. wear of travellers.
The results of variance analyses based on these values are given in Tables, 7,8 and 9 .

\section{3-2. Roughness of Rings}

As a matter of interest, the pre- and post-test roughness of that area of the rings which came

Table 7. Analysis of Variance on the Wear of Ring

\begin{tabular}{lcccc}
\multicolumn{1}{c}{ Factors } & $\mathrm{S}$ & $\phi$ & $\mathrm{V}$ & $\mathrm{F}_{0}$ \\
\hline Viscosity of oil & 495.4 & 1 & 495.4 & 41.37 \\
Type of ring & 405,275 & 5 & $81,05.5$ & $3.95 *$ \\
Interaction & 53,679 & 5 & $10,735.8$ & 1.91 \\
Variations of error & 245.97 & 12 & 20,498 & \\
Total variations & 705,419 & 23 & & \\
\hline
\end{tabular}

Table 8. Analysis of Variance on the Wear of Rings

\begin{tabular}{lccrcc}
\multicolumn{1}{c}{ Factors } & $\mathrm{S}$ & $\phi$ & $\mathrm{V}$ & \multicolumn{1}{c}{$\mathrm{F}_{0}$} \\
\cline { 2 - 5 } \multicolumn{1}{c}{ Viscosity of oil } & 888.2 & 1 & 234.4 & 1.78 \\
Type of ring & $23,109.9$ & 5 & $2,674.2$ & $20.25^{* *}$ \\
Interaction & $4,457.8$ & 5 & 281.7 & 2.13 \\
Variations of error & 1,202 & 12 & 132 & \\
Total variations & $29,657.9$ & 23 & & \\
\hline
\end{tabular}

Table 9. Analysis of Variance on the Coefficient of Friction

\begin{tabular}{lrrrrc}
\multicolumn{1}{c}{ Factors } & \multicolumn{1}{c}{$\mathrm{S}$} & $\boldsymbol{\phi}$ & $\mathrm{V}$ & \multicolumn{1}{c}{$\boldsymbol{F}_{0}$} \\
Viscosity of oil & 234.4 & 1 & 234.4 & 1.78 \\
Type of ring & $13,370.8$ & 5 & $2,674.2$ & $20.25^{* *}$ \\
Interaction & $1,408.3$ & 5 & 281.7 & 2.13 \\
Variations of error & 1.583 .5 & 12 & 132 & \\
Total variations & 16,597 & 23 & & \\
\hline
\end{tabular}

Tabje 10. Roughness of Rings

\begin{tabular}{|c|c|c|c|c|c|c|}
\hline \multirow{3}{*}{ Lubricants } & \multicolumn{6}{|c|}{ rings } \\
\hline & \multicolumn{2}{|c|}{$\begin{array}{l}\text { Conical type } \\
\text { (A) }\end{array}$} & \multicolumn{2}{|c|}{$\begin{array}{l}\text { Vertical type } \\
\text { (A) }\end{array}$} & \multicolumn{2}{|c|}{$\begin{array}{l}\text { Conical type } \\
\text { (B) }\end{array}$} \\
\hline & $a^{*}$ & $b^{* *}$ & a & $\mathrm{b}$ & a & $b$ \\
\hline CL No. 15 & 0.6 & 0.2 & 0.6 & 0.3 & 0.6 & 0.7 \\
\hline \multirow[t]{2}{*}{ CL No. 30} & 0.6 & 0.2 & 0.5 & 0.4 & 0.9 & 0.7 \\
\hline & \multicolumn{6}{|c|}{$\mathrm{OM}$ rings } \\
\hline \multirow{2}{*}{ Lubricants } & \multicolumn{2}{|c|}{$\begin{array}{l}\text { Conical type } \\
\text { (C) }\end{array}$} & \multicolumn{2}{|c|}{$\begin{array}{l}\text { Vertical type } \\
\text { (C) }\end{array}$} & \multicolumn{2}{|c|}{$\begin{array}{l}\text { Horizontal } \\
\text { type (C) }\end{array}$} \\
\hline & a & b & $\mathrm{a}$ & $\mathrm{b}$ & a & $\mathrm{b}$ \\
\hline CL No, 15 & 4.8 & 3.6 & 4.2 & 1.9 & 3.0 & 2.3 \\
\hline CL No. 30 & 3.8 & 2.0 & 5.9 & 2.2 & 2.6 & 2.0 \\
\hline
\end{tabular}

$a^{*}$ : before test; $b^{* *}$ : after test

Note: Values listed are the mean values of measurement of three points on each of four rings tested. 
into contact with the travellers is shown in Table 10.

\section{Conclusions}

With the aid of Ring-Traveller Friction Tester and lubricating oil of various viscosity degrees, the authors have compared the wear of rings and travellers of types at present in common use and the coefficient of the ring-traveller friction. The results show that:

(1) Wear of ring - The viscosity degree of lubricating oil has no bearing on the wear of rings (Table 7). However, the wear of rings differs in amount, depending on the type of the ring. A test of their significative differences has shown that a conical-type $\mathrm{OM}$ ring $(\mathrm{C})$ is subject to heavier wear than the $O M$ ring (C) and five other types.

Every ring develops steady wear in a short time. An OL ring is subject to less wear than an $\mathrm{OM}$ ring. The main reason is the difference between the metals of which they are made and the difference in their hardness.

Nearly all rings tested showed a significative difference between their pre-and post-test roughness, the post-test roughness being smaller in degree.

(2) Wear of travellers The viscosity degree of lubricating oil has a bearing on the wear of travellers (Table 8). On the wear of rings, however, the viscosity degree of lubricating oil has no bearing, in the authors' opinion. The wear of rings seems to be induced by their oiling mechanisms, i.e., the types of rings. Tests have shown that rings of the same type present no significative difference, with the confidence limit of $95 \%$, in the degree of the effect of differences in the viscosity degree of lubricating oil.

Significative differences were observed in the wear of travellers among a conical-type OL ring (B) and five other types, the conical type OL ring (B) showing the highest degree of wear.

The viscosity degree of lubricating oil has a bearing on the wear of a traveller, depending on the type of the ring with which it is combined. The heavier wear which the conical-type OL rings
(B) developed than the other rings is to be explained, in our opinion, chiefly by the difference in the oiling mechanism and by the absence of a proper boundary lubrication layer in the conical type OL.

(3) Coefficient of friction-- The viscosity degree of lubricating oil has no bearing on the coefficent of the ring-traveller friction (Table 9), but the type of the ring does have a bearing on the friction coefficient. The following results have been obtained from a test of the signifcative difference in the friction coefficient among the six types of rings tested:

(3-a) The conical type OL (A) shows the lowest coefficient of friction of all.

(3-b) The conical type OL (B) shows the highest coefficient of friction of all. The other five types show no significative difference among them in friction coefficient. The degree of friction between a self-lubricating ring and a traveller depends to a large extent on the type of the oiling mechanism of the ring.

A self-lubricating ring forms a boundary friction layer between it and the traveller with which it is combined. Not all the area of a boundary friction is formed by a layer of lubricating oil between two conflicting objects. The area of a boundary contact is, in fact, formed by a layer of lubricating oil (fluid or boundary layer) and by a dry layer between two conflicting objects. The larger the layer of lubricating, the smaller the friction between two conflicting objects and their wear.

If follows, then, that a self-lubricating ring should besaturated with a kind of oil which expands the fluid boundary layer between the ring and the traveller it comes into contact with.

If follows, further, that a self-lubricating ring and a traveller it comes into contact with should be made of such metals as reduce their wear in the dry boundary of the ring-traveller contact and that the ring and traveller should be so finished as to be subject to the least possible wear.

\section{Reference}

1) H. Kanai and H. Kubota; J. Text. Mach. Soc., Japanese edition, Vol. 12, No. 5 , p. 361 (1959) 